\title{
Hubungan Antara Kemampuan Berbicara Anak dengan Komunikasi Teman Sebaya
}

\author{
Fauzia Azhari ${ }^{1}$, Aam Kurnia ${ }^{2}$, Zaenal Muftie ${ }^{3}$ \\ ${ }^{1,2,3}$ Pendidikan Islam Anak Usia Dini, Universitas Islam Negeri Sunan Gunung Djati \\ Bandung \\ Jalan Soekarno Hatta Kel. Cimencrang, Gedebage Kota Bandung, Jawa Barat, Indonesia \\ Email: fauziaazhari2@gmail.com ${ }^{1}$, kreatif cemerlang@yahoo.co.id ${ }^{2}$,muftiez@ymail.com³
}

Naskah diterima: 02 Desember 2019, direvisi: 19 Februari 2020, diterbitkan: 31 Maret 2020

\begin{abstract}
Abstrak
Penelitian ini dilatarbelakangi oleh fenomena di lapangan yang diantaranya ada 6 anak mengalami kesulitan dalam berkomunikasi. Kesulitan-kesulitan tersebut membuat komunikasi antar teman sebaya menjadi tidak efektif. Tujuan penelitian ini adalah untuk mengetahui kemampuan berbicara anak, komunikasi teman sebaya anak, hubungan antara kemampuan berbicara anak dengan komunikasi teman sebaya. Metode yang digunakan yakni kuantitatig korelasional. Teknik pengumpulan data pada penelitian ini adalah melalui observasi, wawancara, dan dokumentasi. Adapun hasil perhitungan pada variabel $\mathrm{X}$ diperoleh nilai rata-rata sebesar 66 nilai tersebut berada pada interval 60-69 dengan kategori cukup. Sedangkan, pada variabel Y diperoleh nilai rata-rata 65 nilai tersebut berada pada interval 60-69 dengan kategori cukup. Hubungan antara kemampuan berbicara anak dengan komunikasi teman sebaya diperoleh angka koefisien korelasi sebesar 0,77. Angka koefisien korelasi ini termasuk pada kategori yang kuat/tinggi karena berada pada interval $0,600-0,799$. Hasil uji signifikansi diperoleh harga $t_{\text {hitung }}=434,33$ lebih besar dari harga $t_{\text {tabel }}=2,160$. Artinya $H_{a}$ diterima, dengan kata lain ada hubungan yang signifikan antara kemampuan berbicara anak dengan komunikasi teman sebaya. Adapun besarnya tingkat kebenaran terjadinya korelasi antara kemampuan berbicara anak dengan komunikasi teman sebaya sebesar 36\%. Hal ini menunjukkan $66 \%$ komunikasi teman sebaya dipengaruhi oleh faktor lain.
\end{abstract}

Kata kunci: anak usia dini, berbicara, komunikasi 


\begin{abstract}
This research is motivated by phenomena in the field, including 6 children who bave difficulty communicating. These difficulties make communication between peers ineffective. The purpose of this study was to determine the child's speaking ability, child peer communication, the relationship between children's speaking ability and peer communication. The method used is the quantitative correlation. Data collection techniques in this study were through observation, interviews, and documentation. The results of calculations on the variable $X$ obtained an average value of 66 values are at intervals of 60-69 with enough categories. Meanwhile, the $Y$ variable obtained an average value of 65 values are at intervals of 60-69 with enough categories. The relationship between children's ability to speak with peer communication obtained by the correlation coefficient of 0.77 . This correlation coefficient number is included in the category of strong / high because it is in the interval 0,600-0,799. Significance test results obtained tcount $=434.33$ greater than t table $=2.160$. This means that Ha is accepted, in other words there is a significant relationship between the child's ability to speak with peer communication. The magnitude of the level of truth of the correlation between children's speaking abilities with peer communication by 36\%. This shows that $66 \%$ of peer communication is influenced by other factors.
\end{abstract}

Keywords: early childhood, speaking, communication

\title{
Pendahuluan
}

Pendidikan Anak Usia Dini (PAUD) adalah pemberian upaya untuk menstimulasi, membimbing, mengasuh dan menyediakan kegiatan pembelajaran yang akan menghasilkan kemampuan dan keterampilan pada anak. Pendidikan Anak Usia Dini (PAUD) merupakan jenjang pendidikan sebelum jenjang pendidikan dasar yang merupakan suatu upaya pembinaan yang ditujukan bagi anak sejak lahir sampai usia enam tahun yang dilakukan melalui pemberian rangsangan pendidikan untuk membantu pertumbuhan dan perkembangan jasmani dan rohani agar anak memiliki kesiapan dalam memasuki pendidikan lebih lanjut, yang diselenggarakan pada jalur formal, nonformal, dan informal (Ranggiasanka, 2011).

Pendidikan anak usia dini merupakan salah satu bentuk penyelenggaraan pendidikan yang menitikberatkan pada peletakkan dasar ke arah pertumbuhan dan perkembangan. Pertumbuhan dan perkembangan itu diantaranya perkembangan fisik (koordinasi motorik kasar dan halus), kecerdasan (daya pikir, daya cipta, kecerdasan emosi, 
dan kecerdasan spiritual) sosial emosional (sikap dan perilaku serta beragama), bahasa dan komunikasi, sesuai dengan keunikan dan tahap-tahap perkembangan yang dilalui oleh anak usia dini (Sujiono, 2013).

Raudhatul Athfal (RA) merupakan salah satu lembaga tempat pendidikan anak usia dini yang berada pada jalur formal, di mana pada usia ini merupakan masa keemasan (golden age) khususnya usia 5-6 tahun, dengan adanya RA bertujuan membantu pengembangan potensi yang dimiliki oleh anak antara lain nilai-nilai agama moral, sosial, emosional, kognitif, bahasa, fisik motorik, dan seni, maka dari itu pengembangan potensi yang dimiliki oleh anak tersebut hendaknya dilaksanakan dengan berbagai metode kegiatan belajar yang kreatif dan menyenangkan bagi anak didik. Pada fase keemasan (golden age) inilah peran pendidikan sangat fundamental dan sangat menentukan perkembangan anak selanjutnya.

Menurut Dhienie (2008) perkembangan bahasa merupakan salah satu aspek yang harus dikembangkan, karena bahasa dipelajari dan diperoleh anak usia dini secara alami untuk beradaptasi dengan lingkungannya. Bahasa merupakan sarana komunikasi dengan orang lain. Pada masa usia dini seluruh potensi dan aspek perkembangan yang dimiliki anak dapat dikembangkan secara optimal, dan salah satu aspek perkembangan yang dapat yaitu perkembangan bahasa, khususnya dalam hal keterampilan berbicara pada anak. Berbicara merupakan bentuk komunikasi yang paling efektif, penggunaannya paling luas dan paling penting, oleh sebab itu kemampuan berbicara sangat perlu dimiliki oleh anak. Melatih bicara anak sejak dini akan membantu kemampuan komunikasi dan interaksi sosial anak dengan lingkungan (Ranggiasanka, 2011).

Perkembangan bahasa menjadi salah satu aspek terpenting dalam pendidikan anak usia dini karena bahasa akan memudahkan setiap individu dalam berkomunikasi. Bahasa adalah sarana berkomunikasi dengan orang lain. Dalam pengertian ini tercakup semua cara untuk berkomunikasi dimana pikiran dan perasaan dinyatakan dalam bentuk lisan, tulisan, isyarat, atau gerak dengan kata-kata, simbol, lambang, gambar atau lukisan. Melalui bahasa, setiap manusi dapat mengenal dirinya, sesamanya, alam sekitar, ilmu pengetahuan dan nilainilai moral atau agama (Yusuf, 2011). Idad (2016) mengungkapkan bahwa dengan meluasnya cakrawala sosial anak-anak, anak menemukan bahwa berbicara merupakan sarana penting untuk memperoleh tempat di dalam kelompok. Hal ini membuat dorongan yang kuat untuk berbicara lebih baik, dorongan untuk memperbaiki kemampuannya 
berbicara, dan yang lebih penting anak mengetahui bahwa inti komunikasi adalah bahwa ia mampu mengerti apa yang dikatakan orang lain.

Komunikasi individu mampu membuat suasana menjadi terbuka, memberikan dukungan kepada pihak yang sedang diajak berkomunikasi dan merasa percaya diri untuk berkomunikasi terutama dengan teman sebaya. Teman sebaya menurut Depdiknas (2003) teman adalah kawan, sahabat yang selalu menemani berbagai keadaan baik sukar maupun bahagia. Depdiknas (2003) mengemukakan pengertian sebaya itu sama umurnya, sejajar atau seimbang, contohnya bermain dengan teman atau teman satu kelasnya, untuk dapat menyesuaikan diri dengan teman sebayanya anak harus bisa berkomunikasi dengan baik sehingga dapat diterima di kelompok sebayanya dan dengan adanya teman sebaya anak dapat bercerita tentang masalahnya secara leluasa dan bebas karena memiliki umur yang sama, pikiran dan pendapat mereka cenderung sama sehingga membuat mereka nyaman untuk saling berkomunikasi.

Anak yang mengalami kesulitan berkomunikasi antar teman sebayanya akan mengalami kesulitan untuk bisa menyesuaikan diri dengan teman sebaya dan lingkungannya, apabila kemampuan komunikasi dengan teman sebayanya terhambat itu dapat menyebabkan terhambatnya pemenuhan tugas perkembangannya dan mengganggu perkembangannya yang tentu saja akan menyebabkan tidak terpenuhinya tugas perkembangan selanjutnya. Terhambatnya kemampuan berkomunikasi juga dapat mempengaruhi prestasi belajar siswa, siswa yang kesulitan berkomunikasi, tidak mampu bersosialisasi dan menyesuaikan diri dengan teman sebayanya.

Berdasarkan uraian di atas dan fenomena yang ditemukan di lapangan, penulis tertarik untuk mengadakan penelitian, melalui sebuah judul : "Hubungan antara kemampuan berbicara anak dengan komunikasi teman sebaya”. Tujuan dari penelitian ini adalah untuk mengetahui adanya hubungan antara kemampuan berbicara anak dengan komunikasi teman sebaya.

\section{Metodologi}

Pendekatan dalam penelitian ini adalah pedekatan kuantitatif, karena penelitian ini disajikan dengan angka-angka. Hal ini sesuai dengan pendapat Arikunto dalam bukunya yang mengemukakan penelitian kuantitatif adalah pendekatan penelitian yang banyak dituntut menggunakan angka, mulai dari pengumpulan data, penafsiran terhadap data tersebut, serta penampilan hasilnya (Arikunto, 2010). 
Metode penelitian pada dasarnya merupakan cara ilmiah untuk mendapatkan data dengan tujuan dan kegunaan tertentu (Sugiyono, 2010). Metode yang digunakan dalam penelitian ini adalah metode kuantitatif korelasioal yang digunakan untuk mendapat informasi tentang adanya hubungan antara kemampuan berbicara anak (X) dengan komunikasi teman sebaya $(Y)$. Hubungan antara dua variabel di dalam metode korelasi dalam arti keeratan dalam kedua variabel.

Jenis data yang digunakan dalam penelitian ini adalah kuantitatif. Data kuantitatif adalah jenis data yang dapat diukur atau dihitung secara langsung, yang berupa informasi atau penjelasan yang dinyatakan dengan bilangan atau berbentuk angka (Sugiyono, 2010). Sumber data pada penelitian ini adalah siswa-siswi yang berjumlah 15 orang anak.

Teknik pengumpulan data yang digunakan adalah observasi, dokumentasi dan wawancara. Menurut Nawawi dan Martini dalam (Afifuddin, 2012) Observasi adalah pengamatan dan pencatatan secara sistematik terhadap unsur-unsur yang tampak dalam suatu gejala atau gejala-gejala dalam objek penelitian, dalam lingkup perkembangan mengungkapkan bahasa menurut kurikulum 2013 ada 10 macam tingkat pencapaian perkembangan anak usia 4-5 tahun, namun penulis mengambil 5 macam yang akan dijadikan sebagai indikator kemampuan berbicara anak, diantaranya: 1) Mengulang kalimat sederhana, 2) Menjawab pertanyaan sesuai pertanyaan, 3) Mengungkapkan perasaan dengan kata sifat (baik, senang, nakal, pelit, berani, baik hati, jelek, dsb), 4) Mengutarakan pendapat kepada orang lain, 5) Menyatakan alasan terhadap sesuatu yang diinginkan atau ketidaksetujuan. Diambil 5 macam dikarenakan untuk mempermudah penulis dalam penyusunan instrumen. Pada lembar atau pedoman observasi diperlukan adanya skala penialaian untuk mengukur perkembangan anak berkenaan dengan kemampuan berbicara anak dengan komunikasi teman sebayanya. Dengan menggunakan skala penilaian maka nilai variabel yang digunakan dalam penelitian ini adalah dengan menggunakan skala empat perkembangan anakyaitu BB "belum berkembang", MB "mulai berkembang", BSH "berkembang sesuai harapan”, BSB "berkembang sangat baik" (Enah Suminah, 2015).

Dokumentasi dari asal katanya dokumen, artinya barang-barang tertulis (Arikunto, 2010). Di dalam melaksanakan metode dokumentasi, peneliti mendapatkan data-data tertulis seperti dokumen-dokumen sekolah, misalnya: Visi dan misi, struktur organisasi, keadaan guru, keadaan siswa, keadaan sarana dan prasarana dan standar penilaian. Wawancara (bercakap-cakap) menurut Sukmadinata (2005) merupakan teknik pengumpulan data yang dilaksanakan secara lisan dalam pertemuan tatap muka secara 
individual. Wawancara dalam penelitian ini adalah tanya jawab langsung kepada narasumber yaitu guru.

Teknik analisis data yang digunakan dalam penelitian ini adalah teknik analisis data korelasional. Korelasi dapat didefinisikan sebagai hubungan timbal balik antara dua hal atau lebih, atau keadaan saling ketergantungan dua variabel yang dihitung secara kuantitas. Lebih jelasnya, korelasi adalah suatu teknik untuk mengukur tingkat koefisien hubungan dan pengaruh antara dua variabel. Koefisien korelasi itu digunakan untuk mengukur derajat hubungan dan pengaruh variabel X dengan variabel Y. Variabel X (variabel bebas) pada penelitian ini adalah kemampuan berbicara anak, sedangkan variabel Y (variabel terikat) pada penelitian ini adalah komunikasi teman sebaya (Hayati, 2014).

Analisis data dilakukan menggunakan langkah-langkah berikut: 1) Analisis Parsial, analisis ini dimaksudkan untuk menguji dan menghitung variabel X dan Y secara terpisah, 2) Analisis Korelasi, analisis korelasi ini digunakan untuk mengetahui hubungan antara variabel X (tentang kemampuan berbicara anak) dengan variabel $\mathrm{Y}$ (tentang komunikasi teman sebaya). Koefisien korelasi biasanya diberi simbol $\mathrm{r}$ (korelasi product moment) atau korelasi rho biasa disebut (spearman rank) dan karena kedua komponen masing-masing ditandai dengan huruf $\mathrm{X}$ dan $\mathrm{Y}$, maka koefisien korelasinya disingkat menjadi rxy. Oleh karena itu setelah data terkumpul, sebelum menilai hubungan antara dua variabel yang diteliti, harus dihitung terlebih dahulu koefisien korelasinya. Berdasarkan ketentuan di atas mengenai persyaratan analisis statistik parametris, maka data yang diperoleh diuji normalitas dan regresi linier terlebih dahulu untuk mengetahui data tersebut berdistribusi normal atau tidak menggunakan Chi Kuadrat $\left(\chi^{2}\right)$.

\section{Hasil dan Diskusi}

Berdasarkan hasil penelitian, kemampuan berbicara anak kelompok A di RA Al Muhajir masih termasuk kategori cukup. Hal ini terlihat dari analisis parsial yang menunjukkan bahwa nilai rata-rata kemampuan berbicara anak adalah 66 yang berada pada interval 60-69 yang artinya cukup.

Sementara itu, berdasarkan hasil perhitungan diperoleh mean $=68,9$; dan standar deviasi $=11,9$, nilai chi kuadrat $\left(\chi^{2}\right)$ hitung $=3,36 ;$ dan chi kuadrat $\left(\chi^{2}\right)$ tabel $=5,991$ dengan $\mathrm{db}=2$ pada taraf signifikansi 5\%. Maka dengan demikian $\left(\chi^{2}\right)$ hitung $=3,36<\left(\chi^{2}\right)$ tabel $=5,991$ artinya data variabel $\mathrm{X}$ (kemampuan berbicaraf anak) berdistribusi normal. 
Perkembangan berbicara anak sangat beragam, terdapat anak yang mahir dalam berbicara dan ada anak yang kurang dalam perkembangan berbicaranya, perkembangan berbicara anak bagi kepribadian anak tentunya sangat penting, dengan belajar kemampuan berbicara anakpun dapat mengucapkan bunyi-bunyi artikulasi atau kata-kata yang membuat anak mampu mengekspresikan pikirannya kepada orang lain, sehingga apa yang anak maksudkan dapat dipahami oleh orang lain. Maka dari itu mengajarkan berbicara kepada anak sedari dini merupakan suatu hal yang penting agar kelak anak akan berhasil dakam kehidupan selanjutnya.

Selanjutnya berdasarkan hasil penelitian terhadap komunikasi teman sebaya secara keseluruhan, komunikasi teman sebaya di kelompok A RA Al Muhajir masuk pada kategori cukup. Hal ini ditunjukkan dari analisis parsial yang menunjukkan angka 65 yang berada pada interval 60-69 yang artinya berkualifikasi cukup.

Hasil perhitungan komunikasi teman sebaya diperoleh mean $=67,4$; standar deviasi 11,52 ; nilai chi kuadrat $\left(\chi^{2}\right)$ hitung $=0,62$; dan chi kuadrat $\left(\chi^{2}\right)$ tabel $=5,991$ dengan $\mathrm{db}=$ 2 pada taraf signifikansi 5\%. Karena $\left(\chi^{2}\right)$ hitung $=0,62<\left(\chi^{2}\right)$ tabel $=5,991$ maka data tentang komunikasi teman sebaya berdistribusi normal.

Dalam kehidupan sehari-hari seorang individu selalu berkomunikasi apalagi manusia adalah makhluk sosial yang selalu membutuhkan orang, untuk dapat mengungkapkan apa yang manusia inginkan manusia harus berkomunikasi dengan orang lain. Komunikasi dengan orang lain mampu membuat suasana menjadi terbuka, memberikan dukungan kepada pihak yang sedang diajak berkomunikasi dan merasa percaya diri untuk berkomunikasi terutama jika berkomunikasi dengan teman sebaya. Berkomunikasi merupakan suatu hal yang tidak lepas dalam kehidupan sehari-hari, apalagi pada manusia yang merupakan makhluk sosial yang pastinya memang selalu membutuhkan orang lain, untuk dapat memberikan maksud yang ia inginkan maka manusia harus berkomunikasi dengan manusia yang lainnya

Agar komunikasi menjadi efektif maka dibutuhkan suatu hal yang menumbuhkan hubungan komunikasi antar teman sebaya karena hal tersebut itu sangatlah penting. Aspek psikologisnyalah yang akan diteliti dalam penelitian ini, De Vitto dalam Widjaja (2000) menyebutkan bahwa keterbukaan, empati, dorongan, perasaan positif dan kesamaan itu merupakan hal yang membuat komunikasi agar menjadi semakin efektif Berdasarkan hasil observasi sebagian besar responden memiliki komunikasi teman sebaya yang baik, namun 
ada beberapa anak yang komunikasi teman sebayanya belum maksimal. Hal ini dikarenakan beberapa faktor diantaranya keluarga dan lingkungan sekitarnya.

Hasil penentuan harga koefisien korelasi, besarnya hubungan antara kemampuan berbicara anak dengan komunikasi teman sebaya sebesar 0,77, angka tersebut berada pada interval koefisien 0,600 - 0,799 yang artinya memiliki hubungan yang kuat/tinggi antara kemampuan berbicara anak dengan komunikasi teman sebaya. Dilihat dari hasil perhitungan diperoleh $t_{\text {hitung }}=434,33$ dengan taraf signifikansi $5 \%$ dan untuk diuji derajat kebebasannya sehingga diperoleh $t_{\text {tabel }}=2,160$ yang menunjukkan $t_{\text {hitung }}>t_{\text {tabel }}$ maka dapat diinterpretasikan hipotesis alternatif $(\mathrm{Ha})$ diterima, artinya ada hubungan yang signifikan antara kemampuan berbicara anak dengan komunikasi teman sebaya. Artinya hubungan antara kemampuan berbicara anak dengan komunikasi teman sebaya termasuk kepada kategori kuat/tinggi karena berdasarkan penelitian, kemampuan berbicara anak sudah nampak berkembang dengan baik pada anak kelompok A RA Al Muhajir kecamatan Panyileukan Kota Bandung, faktor penyebabnya adalah subjek penelitian yaitu anak kelompok A yang berusia 4-5 tahun sudah mulai mengerti dan bersikap terbuka pada peneliti saat dilakukan penelitian. Hal ini sejalan dengan pendapat yang dikemukakan oleh Cecep (2011: 139) bahwa dengan berbicara, manusia dapat berinteraksi dengan lingkungan sekitarnya, oleh karena itu berbicara menjadi hal penting bagi kehidupan manusia.

Sama halnya dengan komunikasi teman sebaya anak kelompok A RA Al Muhajir Kecamatan Panyileukan Kota Bandung sudah terlihat berkembang dengan baik, salah satu faktor penyebabnya adalah anak kelompok A yang mampu bergaul atau berkomunikasi dengan teman sebayanya secara perlahan, sesuai dengan yang dikatakan Sugiyo (2005) menyatakan bahwa komunikasi antar pribadi merupakan komunikasi dimana orang yang terlibat dalam berkomunikasi menganggap orang lain sebagai pribadi dan bukan sebagai objek disamakan dengan benda, dan komunikasi antar pribadi merupakan pertemuan antara pribadi-pribadi.

Berdasarkan hasil analisis koefisien determinasi yang telah dilakukan sebelumnya, maka dapat disimpulkan bahwa kemampuan berbicara anak memberikan konstribusi sebesar 36\% terhadap komunikasi teman sebaya anak kelompok A RA Al Muhajir Kecamatan Panyileukan kota Bandung. Sedangkan 64\% kemampuan berbicara anak dipengaruhi oleh faktor lain yang tidak diteliti oleh penulis. 


\section{Penutup}

Berdasarkan hasil perhitungan dapat disimpulkan bahwa : 1) Kemampuan berbicara anak di kelompok A RA Al Muhajir Kecamatan Panyileukan Kota Bandung berkualifikasi cukup. 2) Komunikasi teman sebaya di kelompok A RA Al Muhajir kecamatan Panyileukan Kota Bandung berkualifikasi cukup. 3) Hubungan antara kemampuan berbicara anak dengan komunikasi teman sebaya berada pada kategori kuat/tinggi. Hasil uji signifikansi antara kemampuan berbicara anak dengan komunikasi teman sebaya lebih besar dari harga $\mathrm{t}_{\text {tabel. }}$ Artinya $\mathrm{H}_{\mathrm{a}}$ diterima, dengan kata lain ada hubungan yang signifikan antara kemampuan berbicara anak dengan komunikasi teman sebaya

Berdasarkan hasil penelitian yang dilakukan, ada beberapa saran yang dapat menjadi pertimbangan bagi pihak-pihak yang bersangkutan, diantaranya sebagai berikut: 1) Berdasarkan hasil penelitian diperoleh bahwa kemampuan berbicara anak dan komunikasi teman sebaya anak berada pada kategori sedang, artinya bisa dikatakan bahwa kemampuan tersebut belum optimal maka dari itu guru dan pihak-pihak tertentu harus membantu dalam mengembangkannya agar hal tersebut bisa tercapai dengan baik. 2) Berdasarkan hasil penelitian juga didapatkan bahwa ada hubungan antara kemampuan berbicara anak dengan komunikasi teman sebaya, dan terdapat pada kategori kuat/ tinggi, dengan begitu pihak sekolah RA sudah memberikan pelayanan bimbingan yang baik, maka dari itu semoga pelayanan bimbingan tersebut meningkat lebih baik lagi. 3) Berdasarkan hasil penelitian akan lebih baik jika peneliti tidak hanya menggunakan pedoman observasi di sekolah saja untuk mendapatkan informasi, tetapi juga melibatkan orang tua sebagai sumber informasi, agar data yang diperoleh bisa optimal tidak hanya data yang didapat dari sekolah. 4) Penelitian ini juga dapat dijadikan referensi bagi penelitian selanjutnya yang berhubungan dengan kemampuan berbicara anak dan komunikasi teman sebaya

\section{Daftar Pustaka}

Afifuddin, B. A. (2012). Metodologi Penelitian Kualitatif. Bandung: Pustaka Setia.

Arikunto, S. (2010). Prosedur Penelitian Suatu Pendekatan Praktik. Jakarta: PT. Rineka Cipta.

Cecep Wahyu Hoerudin, E. K. (2011). KAIDAH DAN PELATIHAN BAHASA INDONESLA (Baban Pelajaran MKU Babasa Indonesia). Bandung: CV. Insan Mandiri.

Depsiknas. (2003). Kamus Besar Babasa Indonesia. Jakarta: Balai Pustaka.

Dhienie, d. (2008). Metode Pengembangan Prilaku dan Kemampuan Dasar Anak Usia Dini. Jakarta: Universitas Terbuka. 
Enah Suminah, Y. S. (2015). Pedoman Penilaian Pembelajaran Pendidikan Anak Usia Dini. Jakarta: Direktorat Pembinaan Pendidikan Anak Usia Dini.

Hayati, T. (2014). Pengantar Statistika Pendidikan. Bandung: Insan Mandiri.

Ranggiasanka, A. (2011). Serba-Serbi Pendidikan Anak. Yogyakarta: Hanggar Kreator.

Sugiyo. (2005). Komunikasi Antar Pribadi. Semarang: UNNES Press.

Sugiyono. (2010). Metode Penelitian Pendidikan (Cetakan ke 10). Bandung: Alfabeta.

Suhada, I. (2016). Psikologi Perkembangan. Bandung.

Sujiono. (2013). konsep Dasar Pendidikan Anak Usia Dini. Jakarta: Indeks.

Sukmadinata, N. S. (2005). Metode Penelitian Pendidikan . Bandung: Remaja Rosdakarya.

Widjaja. (2000). Ilmu Komunikasi Pengantar Studi. Jakarta: Rineka Cipta.

Yusuf, S. (2011). Perkembangan Peserta Didik. Depok: Rajawali Press. 